\title{
ANALISIS MALWARE DENGAN METODE SURFACE DAN RUNTIME ANALYSIS
}

\author{
Febriyanti Panjaitan ${ }^{1}$, Helda Yudiastuti ${ }^{2}$, Maria ulfa ${ }^{3}$ \\ Dosen Universitas Bina Darma ${ }^{1,2,3}$ \\ Jalan Jenderal Ahmad Yani No.3 Palembang \\ Sur-el : febriyanti_panjaitan@binadarma.ac.id ${ }^{1}$, helda.yudiastuti@binadarma.ac.id ${ }^{2}$, \\ Maria.ulfa@binadarma.ac.id ${ }^{3}$
}

\begin{abstract}
Malware is a virus that has many ways of infecting data and giving dangerous damage, such as what happened to a hospital in Palembang, malware attacks all existing data so that the data cannot be accessed by related parties. Malware not only attacks data, but can damage operating systems that are vulnerable to being infiltrated, one of which is the Windows operating system. Malware is very difficult to identify with the original data file if it does not use the help of analysis tools, with this research will conduct analysis and testing of malware behavior, so that the pattern and type of malware can be identified with 2 analysis methods, namely the surface analysis method (Pestudio, Strings). , Exeinfo and Virus) and runtime analysis (Regshot, CaptureBAT, Noriben Malware Analysis). The analysis carried out will create a work environment as a testing ground, so that it does not interfere with the main system that has been running. With the trials conducted, it was found that the file with the name "games.exe" can be said to be malware because it has strings and can duplicate itself to the system32 folder as evidenced by MD5.
\end{abstract}

Keywords: Malware, Surface Analisis, Runtime Analisis, Windows

\begin{abstract}
Abstrak : Malware salah satu virus yang memiliki banyak cara dalam menginfeksi sebuah data dan dapat memberikan kerusakan yang berbahaya, seperti yang terjadi pada salah satu rumah sakit ternama, dimana malware menyerang seluruh data yang ada sehingga data tidak dapat diakses kembali oleh pihak yang terkait. Malware bukan hanya menyerang data, tetapi dapat merusak sistem operasi yang sedang digunakan karena rentan untuk disusupi, salah satunya adalah sistem operasi windows. Malware sangat sulit di intifikasi dengan file data yang asli jika tidak menggunakan bantuan tools analisis, dengan hal tersebut penelitian akan melakukan analisis dan pengujian terhadap tingkah laku malware, sehingga dapat diketahui pola dan jenis malware dengan 2 metode analisis yaitu metode surface analisis (Pestudio, Strings, Exeinfo dan Virus) dan runtime analisis ( Regshot, CaptureBAT, Noriben Malware Analysis). Analisa yang dilakukan menciptakan lingkungan kerja sebagai tempat uji coba, sehingga tidak menggangu sistem utama yang telah berjalan. Dengan uji coba yang dilakukan, jadi didapatkan bahwa File dengan nama "games.exe" dapat dikatakan malware karena memiliki strings dan dapat menggandakan diri ke folder system32 yang dibuktikan dengan MD5.
\end{abstract}

Kata kunci: Malware, Surface Analisis, Runtime Analisis, Windows

\section{PENDAHULUAN}

Malicous Sofware atau dikenal sebagai Malware merupakan perangkat lunak yang didesain untuk melakukan aktifitas berbahaya atau perusak perangkat lunak [1]. Malware terbagi menjadi 9 kelompok : Backdoor, Botnet,
Downloader, Information-stealing Malware, Launcher, Rootkit, Scareware, Spam-sending Malware, Worm atau Virus [2]. Kelompok malware ini terus berkembang semakin mutakhir, kompleks dan selalu melakukan perubahan guna mencari-cari celah keamanan dengan membuat banyak varian pada pola serangan. Tren malware yang menjadi 
perbincangan saat ini salah satunya Ransomware Wannacry yang pernah terjadi pada rumah sakit yaitu Dharmais, ransomwere yang berjenis malicious software menyerang komputer dengan mengenkripsi seluruh data yang ada di rumah sakit, sehingga pengguna tidak bisa untuk mengakses data itu kembali [3]. Masuknya malware kedalam sistem bisa dengan berbagai cara, seperti diselundupkan didalam kumpulan file atau aplikasi tertentu sehingga pengguna tidak menyadari bahwa perangkat komputer yang digunakan telah disusupi malware.

Malware memiliki banyak cara dalam menginfeksi, seperti : email attachment, script dari halaman web, link ke dalam halaman web yang merupakan file yang siap di install. Melakukan bug pada sistem operasi, USB Driver, file sharing dan juga aplikasi bajakan [2]. Malware juga sering disamarkan dengan menggunakan file umum seperti Driver (.drv), data (.dat), library (.lib), temporary (.tmp) dan lain sebagainya,yang terkadang pengguna tidak menyadari kehadiran file tersebut didalam komputer yang digunakan [1].

Beberapa sistem operasi rentan terhadap yang namnya sebuah malware salah satunya sistem operasi, beberapa yang popular yang dapat menginfeksi sistem operasi windows yaitu shortcut, LNK.Autostart, Sality dan Ramit yang pernah menjadi penyebaran tertinggi sebuah malware di Indonesia pada tahun 2010 sampai dengan 2013. [4]

Analisis malware diperlukan untuk mengetahui (1) ciri-ciri sebuah malware, (2) melihat pola serangan, (3) apa saja efek yang ditimbulkan yang nantinya memberikan informasi perbaikkan sistem, (4) mengantisipasi apabila terjadi serangan malware. Dalam menganalisis malware dapat menggunakan metode Surface Analysis dan Runtime Analysis.

Surface Analisis adalah metode yang menganalisis jenis file asli, ukuran file sebenarnya, sehingga memberikan informasi untuk mengetahui malware yang tersembunyi atau menyamar didalam file lain. Sedangkan Runtime Analysis, menjalankan atau mengaktifkan file yang diperiksa dalam mendapatkan informasi perilaku dari program yang menjalankan skenario jahat dan dapat dianalisis dampak terhadap sistem yang ada [1].

Dengan latar belakang yang ada, peneliti bermaksud melakukan pengujian analisis tingkah laku malware yang akan diterapkan pada sistem operasi windows, sehingga dapat diketahui pola serangan yang nantinya akan dikelompokkan berdasarkan pola-pola sebuah malware. Analisa dilakukan dengan menciptakan lingkungan kerja sebagai tempat uji coba sehingga tidak menggangu sistem utama yang telah berjalan.

\section{METODOLOGI PENELITIAN}

\subsection{Metode Analysis}

Metode yang digunakan dalam penelitian ini adalah surface analysis dan runtime analysis. Kedua metode ini merupakan pendekatan umum yang digunakan dalam mendeteksi file atau program telah teridentifikasi sebagai jenis malware atau bukan.[1]. 


\subsubsection{Metode Surface Analysis}

Kegiatan pertama dalam metode ini menyiapkan bahan-bahan yang diperlukan sampel maupun tool, tools yang digunakan adalah Pestudio, Strings, Exeinfo dan Virus total. Tahapan dari metode ini:

\section{a. File Attribute Analysis}

Pada tahapan ini tool yang digunakan adalah Pestudio, aplikasi ini digunakan untuk melihat atribut dari sample malware, mulai dari MD5, hash, strings, header sebagai kebutuhan dari analisa.

\section{b. Fuzzy Hashing}

Tahapan ini memastikan bahwa sample malware yang dianalisa sama dengan sample aslinya, apakah terjadi perubahan pada MD5 dan hash nya ketika file "games.exe" dipindahkan dari windows ke remnux, maka perlu dilakukan verifikasi melalui kecocokan nilai MD5 yang ada pada file. Tools yang digunakan MD5SUM dan ssdeep dalam mencocokan nilai MD5 dan hash.

\section{c. Packer Check}

Kegiatan dalam tahapan ini untuk melihat apakah file tersebut di packing atau tidak, karena jika file di packing maka informasi yang akan ditampilkan dalam menganalisa stringnya akan di enkripsi. Jika file yang akan dianalisa di pack maka perlu melakukan unpack untuk dapat melihat strings dan membutuhkan tool yang sama digunakan untuk membongkarnya yaitu dengan Exeinfo

\section{d. Analisis String}

Strings adalah squence of characters sebuah program, sehingga mencari string dalam malware merupakan hal penting untuk mengetahui pola kerja dari malware. Biasanya string sebuah file malware, akan menampilkan IP address pencarian file, menduplikat file, dan mengirimkan message. Tool yang digunakan adalah Pestudio pada sistem operasi windows, dan Yara dan String pada sistem operasi renmux e. Malware Scan

Setelah diterapkan ke 4 tahapan, selanjutnya file yang dijadikan sample diperiksa apakah telah terdeteksi malware dengan menggunakan MD5 yang di upload pada [5] Jika file terdeteksi malware, maka kita dapat melihat informasi apa saja yang didapat yang setelah dianalisa antivirus, sehingga lebih fokus dan telah terarah.

\subsubsection{Metode Runtime Analysis}

Setelah menyelesaikan tahapan pada metode surface analysis, maka akan dilanjutkan pada metode runtime analysis dengan menjalankan file. Metode ini menggunakan tools Regshot, CaptureBAT, Noriben Malware Analysis. Tahapan metode ini adalah:

a. Melihat Perubahan Registry

Tools yang digunakan pada tahapan ini adalah regshot untuk melihat perubahan pada registry ketika file dijalankan. Tool ini melakukan dua kali pemeriksaan/shoot, shoot yang pertama untuk mendapatkan registry sebelum file dijalankan. Selanjutnya melakukan Shoot yang kedua dan tunggu beberapa saat sampai selesai, kemudian dilihat perubahan apa saja yang telah terjadi dengan melakukan compare untuk mendapatkan hasil analisa. Hasil shoot akan ditampilkan dalam bentuk teks pada notepad, dan kemudian melakukan analisa pada registry 
b. Melihat aktivitas malware didalam sebuah jaringan

Disini dapat dilakukan monitoring terhadap jaringan dengan menggunakan CaptureBAT. Aplikasi ini bekerja dengan cara memonitoring aktivitas jaringan sebuah sistem operasi windows dan mengubahnya dalam bentuk capture yang dapat dibuka dengan menggunakan aplikasi wireshark. Aplikasi memantau apa saja yang dilakukan ketika file "game.exe" dijalankan

c. Analisa otomaris dengan Noriben Malware Analysis Sanbox

Analisa ini dilakukan untuk lebih menguatkan hasil yang didapat dari tahapan sebelumnya dengan menggunakan tools Noriben yang dapat mencatat aktivitas dalam sebuah sistem operasi secara otomatis yang bekerjasama dengan tool procmon, agar mendapatkan hasil yang optimal dan lebih akurat.

\subsection{Sample Malware}

Dalam penelitian ini sample malware yang dianalisa adalah "games.exe", yang akan diidentifikasi apakah termasuk kedalam jenis malware, dan jenis malware yang seperti apa, serta bagaimana perilakunya ketika berhasil menginfeksi sebuah sistem operasi yang akan digunakan sebagai sample yaitu windows.

\subsection{Alat dan Bahan}

\section{a. Hardware dan Software}

Spesifikasi Hardware dan SoftwareDalam menganalisis malware dibutuhkan beberapa alat dan bahan yang terdiri dari perangkat keras (Hardware) dan perangkat lunak (Software), yang terdapat pada table 1 dan table 2
Tabel 1. Spesifikasi Hardware

\begin{tabular}{ll}
\hline Hardware & Spesifikasi \\
\hline Laptop & Processor intel (R) \\
& Pentium(R) CPU B940 \\
& 32 Bit \\
Flasdisk & Kapasistas 8GB \\
\hline
\end{tabular}

Tabel 2. Spesifikasi Software

\begin{tabular}{lc}
\hline Software & Spesifikasi \\
\hline Sistem Operasi & \\
Windows & Pro 64-bit \\
Remnux & Versi 4.0 \\
Tools metode Surface & Analysis \\
Pestudio & Versi 8.50 \\
Exeinfo & Versi 0.0.4.4 \\
Md5sum & Malware Scan \\
ssdeep & Malware Scan \\
Yara Rule & String analysis \\
www.virustotal.com & Malware Scan \\
Tools metode Runtime & Analysis \\
Process Hacker & Task Manager \\
CaptureBAT & Runing in Windows \\
Noriben Sanbox & Versi 1.7.2 \\
Wireshark & Versi 2.4.11 \\
\hline
\end{tabular}

b. VMare

VMware adalah teknologi buatan Dell yang menyediakan platform perangkat lunak (software) untuk melakukan virtualisasi [6], dengan software ini peneliti bisa menginstal beberapa system operasi yaitu linux dan windows pada waktu yang bersamaan tanpa kita merestart ulang PC atau bisa dikatakan PC didalam PC

\section{c. Remnux $v 4.0$}

Remnux adalah sistem operasi yang berbasis linux Ubuntu, yang membedakkan Remnux menyediakan lebih banyak tools dalam melakukan analisis pada malware. Tools yang akan digunakan untuk menganalisa malware yang berada pada file berbentuk "exe" [7].

d. Wireshark

Salah satu dari tools Network Analyszer adalah wireshark, yang banyak disukai karena menggunakan antarmuka yang baik atau Graphical User Interface (GUI), tool ini tersedia 
opensource dan mampu menangkap semua paket data atau informasi yang berada dalam jaringan [8].

\section{e. Registry}

Registry adalah sebuah ruang control utama dari sebuah system operasi windows, dikarenakan registry adalah basis data dan sebagai pusat pengaturan/konfigurasi windows. [6]

\section{HASIL DAN PEMBAHASAN}

\subsection{Metode Surface Analysis}

Metode ini akan mengidentifikasi unsurunsur yang dterdapat didalam sebuah file yang dicurigai sebagai malware.

\subsubsection{File Attribute Analysis}

Tahapan ini berhasil mendapatkan atribut dari sample dengan tipe executable pada sistem 32-bit dan MD5 melalui sistem operasi Windows dan Remnux.

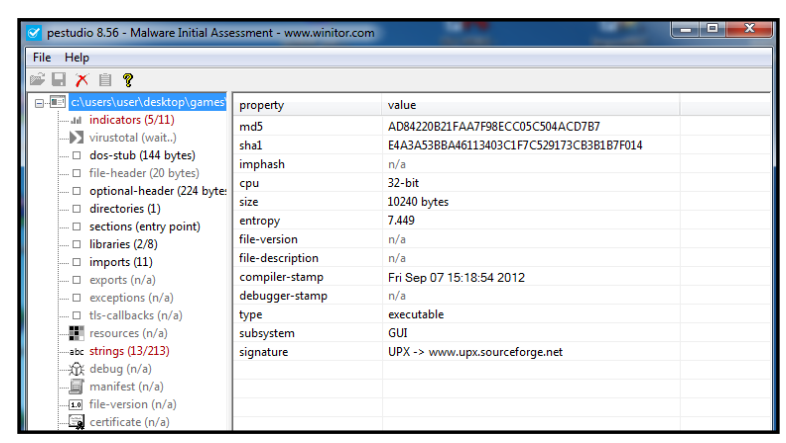

Gambar 1. File Atrribute di Pestudio Windows.

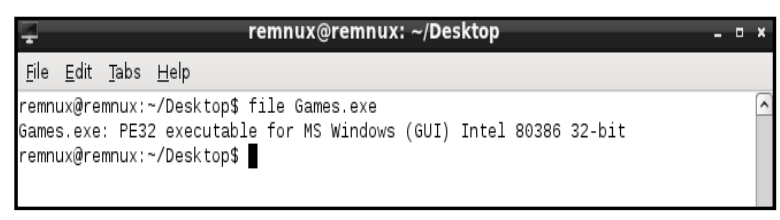

Gambar 2. File Atrribute di Remnux
Selanjutnya melihat indikator yang dihasilkan pestudio dengan menggunakan angka 1 sampai 9 sebagai alamat, angka 1 dan 2 menunjukkan bahwa file tersebut memiliki tingkat bahaya yang cukup tinggi, karena memiliki kemampuan yang biasanya ada pada malware, seperti memodifikasi registry dan terdapat blacklist pada stringnya yaitu melakukan perubahan pada file, menghapus serta merusak. Maka, semakin banyak angka 1 dan 2, maka semakin besar pula kemungkinan file tersebut merupakan sebuah malware. Terindentifikasi file "game.exe" terdapat 5 dan 11 indikator yang menunjukkan bahwa file tersebut kemungkinan merupakan file yang berbahaya.

\begin{tabular}{|c|c|c|}
\hline Q pestudio 8.56 - Malware litital Ass & essment-wwwwinitorcom & $\sqrt{2}$ \\
\hline File Help & & \\
\hline 回自早 & & \\
\hline 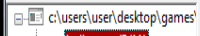 & indicator (11) & severity \\
\hline iil Indicators(5/11) & The file modfifies the Registry & 1 \\
\hline 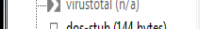 & The file references the protection of the Virtual Address spacce & 1 \\
\hline 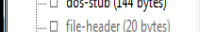 & The file cortains 13 blacklisted strings & 1 \\
\hline 口 optional-header [224 byte: & The first section (name:UDX) is witable & 1 \\
\hline 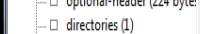 & The entry point $(0: 000008-10)$ is outside the first section & 1 \\
\hline$\square$ sections (entry point) & The fille references other process(es) & 2 \\
\hline$\square$ प libraries (2/8) & The file is resource-less & 3 \\
\hline$\square$ import (11) & The file has no Version & 7 \\
\hline 口 exports (n/a) & The file does not contain a Certficate & 7 \\
\hline . Exceptions $(n / \mathrm{d})$ & The file ignores Dista Execution Prevertion (DEP) & 8 \\
\hline $\begin{array}{l}\square \text { Hsc-callbadcs }(n / \mathrm{a}) \\
\mathbf{m}\end{array}$ & The file ignores Address Spoce Layout Randomization (ASLR) & 8 \\
\hline
\end{tabular}

Gambar 3. Indikators file Games.exe

\subsubsection{Fuzzy Hashing}

Dalam mengindentifikasi keaslian malware yang akan dianalisa, kedua file diletakkan dalam satu folder yang sama untuk memudahkan pencocokan MD5 dan hash pada sistem operasi. Terlihat pada gambar 4 menunjukkan bahwa MD5 dan hash memiliki nilai kesamaan $100 \%$ yang berarti file yang dianalisa sama persis file asli. 


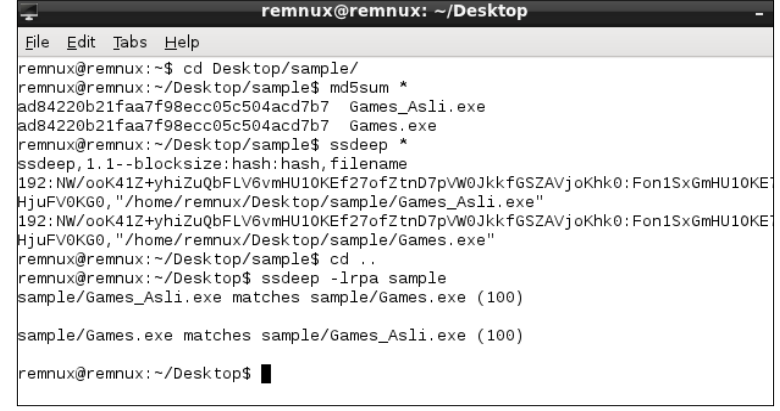

Gambar 4. Fuzzy Hasing file sampel

\subsubsection{Packer Chack.}

Sebelum mulai melakukan analisa file harus di unpacking untuk dapat melihat string yang ada pada file tersebut, agar tidak mempersulit dalam melakukan analisa nantinya. Tool unpacking yang didapat dari informasi exeinfo adalah UPX 0.89 dari [9], Setalah tool didapat maka tinggal dijalankan melalui command prompt (CMD) dengan menempatkan file satu folder bersama dengan tool tersebut.

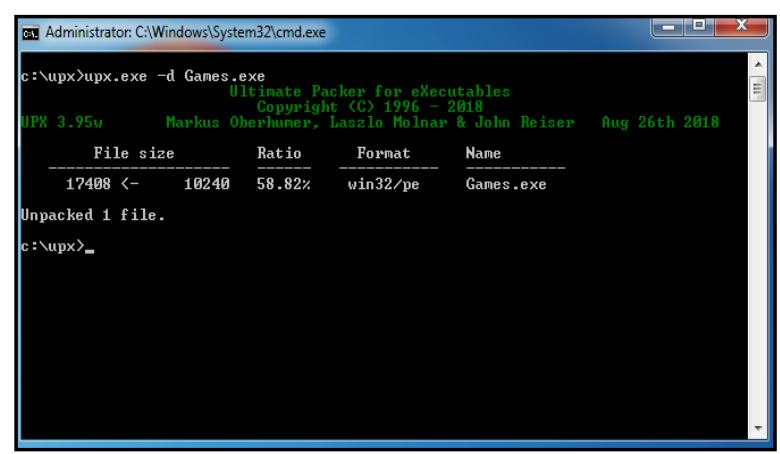

Gambar 5. Hasil unpacking file Games.exe

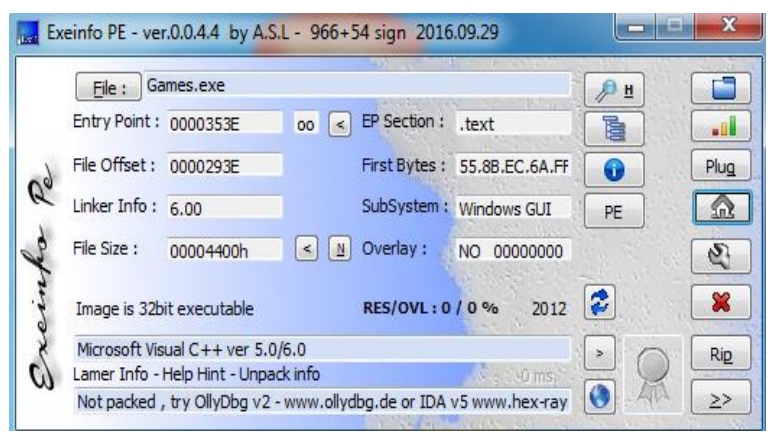

Gambar 6. Hasil setelah unpacking pada Exeinfo
Kemudian pada Portable Executable (PE) Section terdapat file PE yang berisi header dan beberapa bagian yang penting.

- .text : berisikan kode yang dapat di eksekkusi

- .rdata : menampung dan membaca data yang dapat diakses secara global.

- data : menyimpan data global yang dapat di akses hanya melalui program saja.

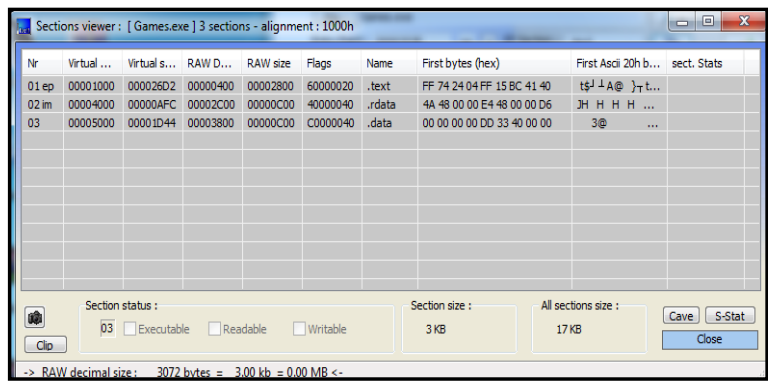

Gambar 6. Tampilan Portable Executable (PE) Section

Maka dapat melihat perubahan string pada file yang tampil lebih banyak dari sebelum file di unpacking seperti pada gambar 7 dan Gambar 8.

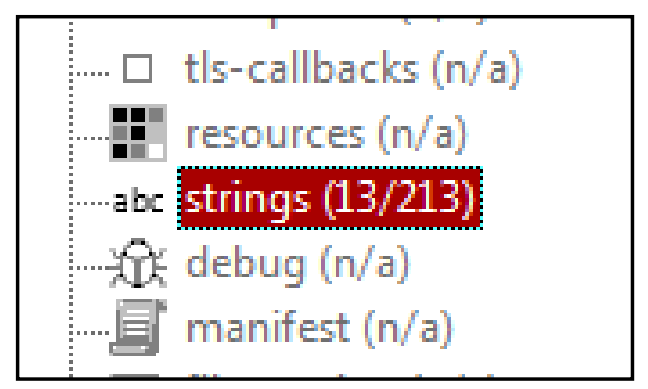

Gambar 7. File sebelum Unpacking

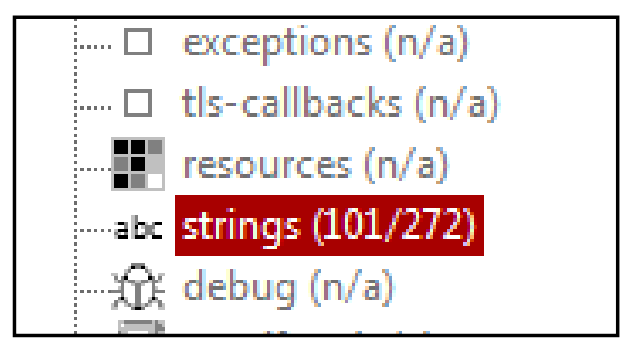

Gambar 8. File sesudah Unpacking 


\subsubsection{String analysis}

Tools yang digunakan selanjutnya adalah Yara untuk menganalisa keberadaan string pada file dengan aturan yang sudah dibuat seperti pada gambar 12 dibawah ini.

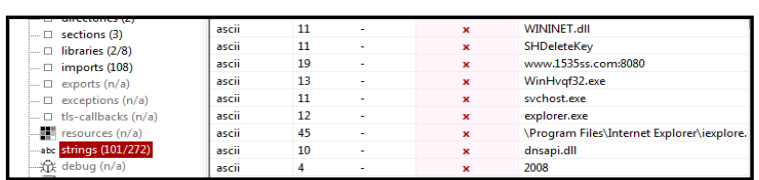

Gambar 11. Analisa string dengan Pestudio di Windows.

Dari informasi yang didapat, file tersebut memliki 101 blacklist dari 272 jumlah string, hal ini menunjukkan bahwa file tersebut banyak melakukan tindakan ketika di eksekusi. Hasil yang didapat diantaranya terlihat jelas bahwa file tersebut mengakses sebuah alamat web melalui port 8080, dengan menjalankan file "WinHmks32.exe" dan "svchost.exe".

\section{Gambar 9. Yara Rule.}

Dengan menggunakan aturan ini akan dilihat ada berapa string yang didapatkan Yara Rule. Semakin banyak string yang didapatkan maka semakin besar kemungkinan file merupakan sebuah malware karena aturan yang ada pada Yara Rule mampu membaca string pada program.

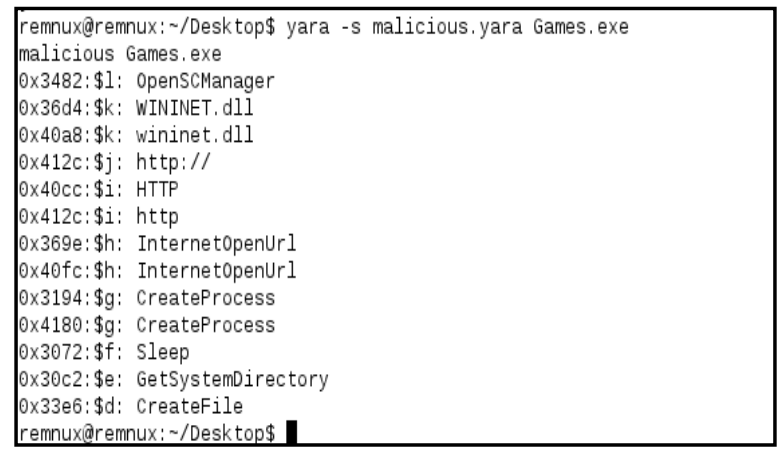

\section{Gambar 10. Hasil Yara Rule}

Selanjutnya menggunakan Pestudio untuk melihat string yang ada pada program, dan telihat bahwa blacklist dari program menampilkan banyak informasi bahwa file tersebut besar kemungkinan adalah sebuah malware.

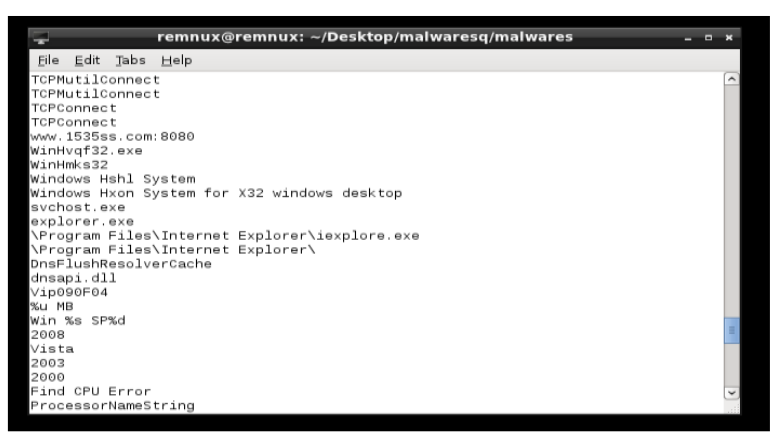

Gambar 12. Analisa string dengan Strings di

\section{Remnux.}

\subsubsection{Malware Scan}

Pada tahap ini hasil scan dari sample menunjukkan bahwa file belum terdeteksi sebagai sebuah malware melalui MD5, dari hal tersebut kita mencari lebih banyak pada metode selanjutnya dengan cara mengeksekusi file.

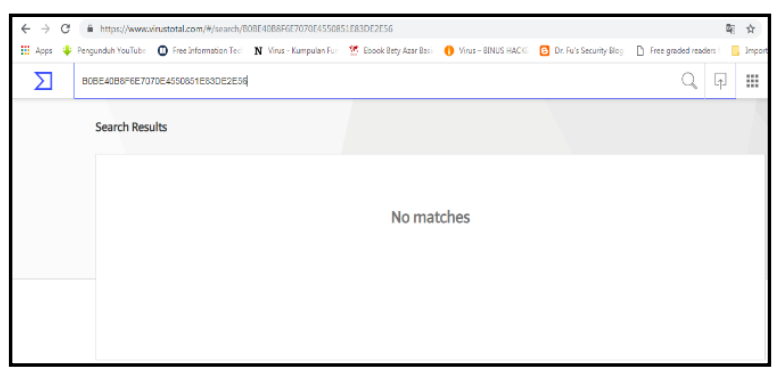

Gambar 13. Scan file di Virus Total. 


\subsection{Metode Runtime Analysis}

Tahap ini menjalankan file yang akan dianalisa untuk melihat aktivitas yang dilakukan, sehingga dapat dinilai apakah file tersebut merupakan malware atau bukan

\subsubsection{Melihat Perubahan Registry}

Dengan menggunakan Regshot dapat dilihat perubahan yang terjadi pada registry setelah file dijalankan. Terlihat file melakukan beberapa perubahan dengan menambahkan beberapa file registry.

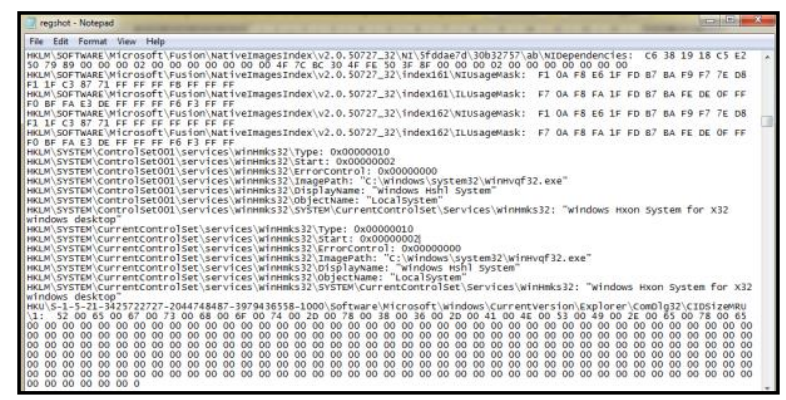

Gambar 14. Hasil monitoring Regshot

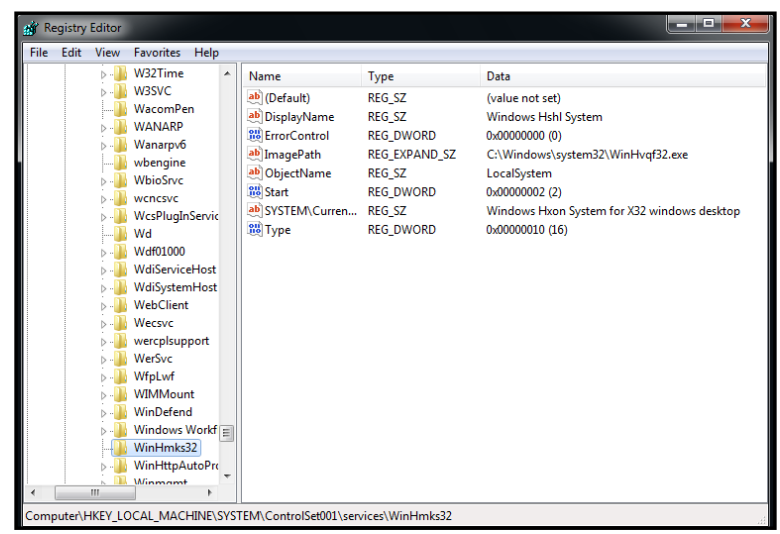

Gambar 15. Penambahan file registry

\subsubsection{Melihat aktivitas malware didalam sebuah jaringan}

Aplikasi ini memeriksa semua file yang sedang berjalan didalam sistem, mirip seperti task manager yang ada pada windows, namun lebih jelas dan rinci. Pada proses menjadi Hacker terlihat adanya proses svchost.exe. ketika file "games.exe" di eksekusi. Ketika file "svchost.exe" yang diterminate, maka dapat dilihat pada wireshark layanan yang meminta akses ke www.1535ss.com berhenti.

\begin{tabular}{|c|c|c|c|c|c|c|}
\hline sppsvc.ere & 3328 & & & $4.97 \mathrm{MB}$ & N...INETWORK SERVICE & Microsofft Software Protection... \\
\hline 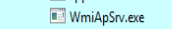 & 2816 & 0.04 & & $1.13 \mathrm{MB}$ & NT AUTHORTTY SYSTEM & WMI Performance Reverse Ad.... \\
\hline SoogleUpdate.ere & 3652 & & & $3.23 \mathrm{MB}$ & NT AUTHORITYSYSTER & Google Installer \\
\hline Trustedinstaller.ere & 3808 & 56.33 & $6.99 \mathrm{kB} / \mathrm{s}$ & $7.21 \mathrm{MB}$ & NT AUTHORTM SYSTEN & Windows Modules Installer \\
\hline (10] Isass,exe & 500 & 0.63 & & $2.25 \mathrm{MB}$ & NT AUTHORITY SYSTEN & Local Security Authority Proce... \\
\hline [-1] Ism.ere & 508 & & & $1.05 \mathrm{MB}$ & NT AUTHORTTY SVSTEN & Local Session Manager Senvice \\
\hline (1) curss.ere & 396 & 0.20 & $264 \mathrm{~B} / \mathrm{s}$ & 4.17 MB & NT AUTHORTTY SYSTEN & Client Sever Funtime Process \\
\hline 4inlogon.ere & 432 & & & $1.67 \mathrm{MB}$ & NT AUTHORTIY SYSTEN & Windows Logon Application \\
\hline 4 explorer, exe & 1608 & 2.47 & & $30.36 \mathrm{MB}$ & WIN-SKH-BBATFUEB Use & Windows Explorer \\
\hline vinin vmtoolsd.exe & 1932 & 0.30 & $1.79 \mathrm{kB} / \mathrm{s}$ & $11.71 \mathrm{MB}$ & WIN-5KH-88ATFUEB Use & VMware Tools Core Service \\
\hline D ProcessHacker.ere & 3056 & 2.06 & & $6.82 \mathrm{MB}$ & WIN-5KHB8ATFUEB Use & Process Hacker \\
\hline Ti] schost.exe & 1892 & 0.16 & & $0.98 \mathrm{MB}$ & NT AUTHORTY SYYTEN & Host Processs for Windows Ser... \\
\hline $0.00 \% \mathrm{P}$ & & & & & & \\
\hline
\end{tabular}

Gambar 16. Proses yang berjalan pada system dengan Process Hacker

\subsubsection{Analisa otomatis dengan Noriben Malware Analysis Sanbox}

Dengan menggunakan captureBAT akan melihat perilaku dari file "games.exe" setelah file tersebut di eksekusi. Eksekusi dilakukan dengan menginstall file captureBAT pada windows, selanjutnya mempersiapkan wireshark pada remnux untuk melihat paket data yang berjalan selama proses berlangsung pada captureBAT. CaptureBAT akan menyimpan hasil capture secara otomatis bentuk "capture_11102018_1056.zip".

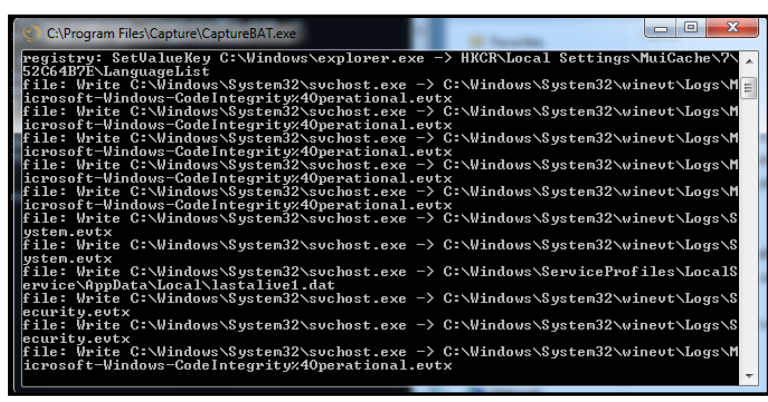

Gambar 17. Gambar CaptureBAT.

\subsubsection{Analisa menggunakan Noriben Malware} Analysis Sanbox

Noriben bekerjasama dengan procmon dalam memonitoring aktivitas yang terjadi dalam 
sistem, sehingga perlu meletakkan file procmon dalam satu folder. Tempatkan sample di desktop agar mudah ditemukan, dan selanjutnya mengecek IP yang ada pada windows, jika semua sudah selesai berahli ke sistem operasi remnux untuk menjalankan wireshark yang nantinya akan memonitoring semua lalulintas jaringan dengan ditambah sebuah perangkat lunak Inetsim untuk memanipulasi jaringan lokal, sehingga seperti terlihat berjalan pada jaringan internet.

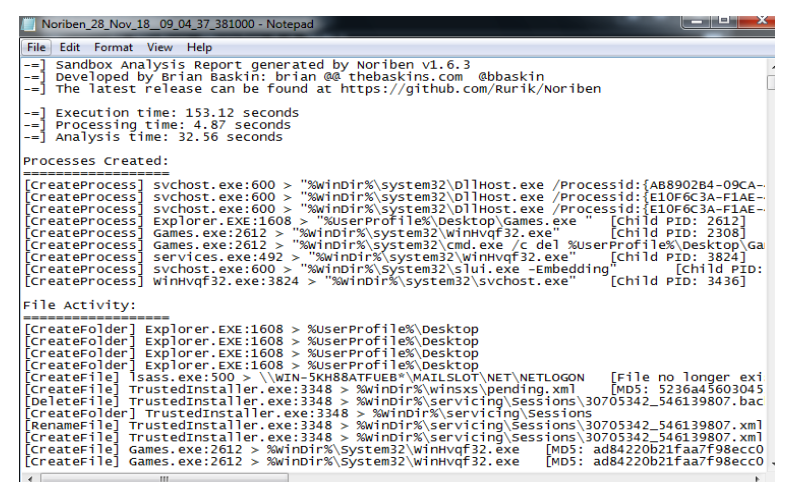

Gambar 18. Hasil Analisa Noriben

Hasil dari analisa Noriben menunjukkan pada proseses crated adanya proses "WinHvqf32.exe" ketika file "games.exe" dijalankan dan file tersebut meminta layanan "svchost.exe" merupakan bagian integral dari sistem operasi windows untuk melalui layanan service yang dapat melakukan automatic update, hal ini menjadi mungkin bagi file "games.exe" untuk mengakses jaringan. Pada file activity juga menampilkan adanya aktivitas pembuatan file "WinHvqf32.exe" oleh "games.exe"yang memiliki MD5 sama persis di lokasi system32. Ada yang menarik dengan file ini, ketika dicari secara biasa tidak bisa ditemukkan, karena file di super hidden atau disembunyikan dengan sangat baik, sehingga meskipun pengaturan show hidden folder, file dan driver sudah diaktifkan, file tetap tidak muncul dan terlihat, dari hal tersebut dapat menggunakan trik tambahan untuk menampilkan file yang sudah di super hidden dengan cara masuk ke commmand prompt ( $\mathrm{cmd}$ ), ketika "dir/ah" seluruh file akan tampil semua termasuk yang telah di hidden. Selanjutnya akan menampilan file tersebut di windows explorer karena meskipun sudah tampil di $\mathrm{cmd}$, file tersebut belum tampil pada windows explorer.

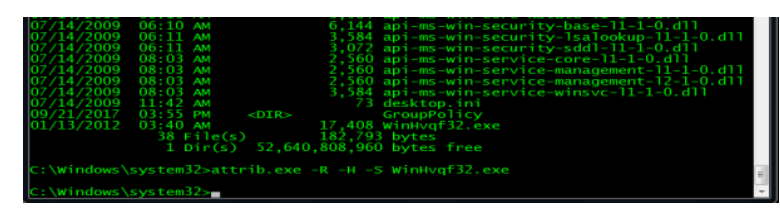

Gambar 18. Menampilkan file yang hidden

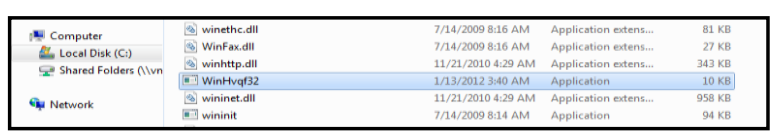

Gambar 19. file di system32 yang tampil

Jika semua telah dilakukan, file akan terlihat pada windows explore dan dapat menganalisa apakah benar file dengan file "games.exe" dengan menggunakan pestudio.

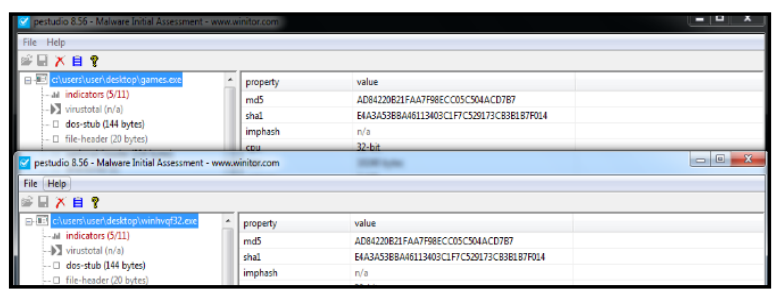

Gambar 20. Gambar kecocokan MD5 di Pestudio

Monitoring paket data jaringan menggunakan wireshark.

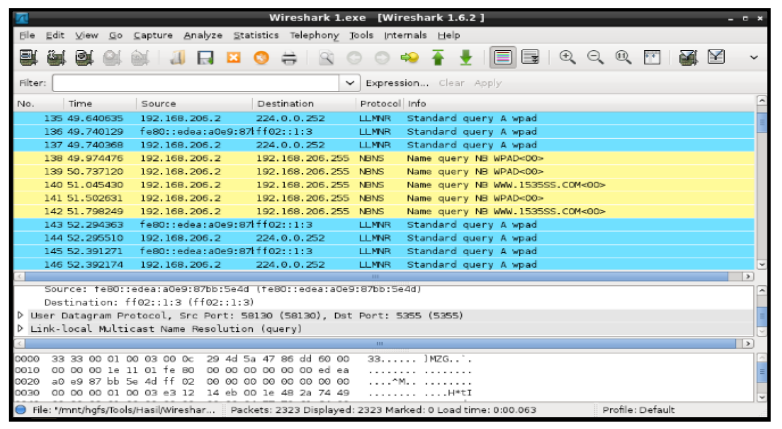

Gambar 21. Hasil Capture Wireshark 
Hasil monitoring yang dilakukan wireshark ketika file "games.exe" di eksekusi pada sistem operasi windows telah menangkap adanya komunikasi yang dilakukan IP 192.168.206.2 kepada 192.168.208.225 menggunakan protocol NBNS. Rangkuman dari analisis dengan metode surface analysis dan runtime analysis dirangkum pada tabel 2 dan tabel 3.

Tabel 2. Hasil Analisa metode Surface Analysis

\begin{tabular}{|c|c|c|c|c|}
\hline & & Analysi & & \\
\hline No & Tahapan & & face Ana & ysis \\
\hline & & Tool & Hast & Temuan \\
\hline 1 & File & Pestudio & File & Games.exe \\
\hline & Attribute & & Name & \\
\hline & analysis & & MD5 & $A D 84220$ \\
\hline & & & & $B 21 F A A 7$ \\
\hline & & & & F98ECCO \\
\hline & & & & $5 C 504 A C$ \\
\hline & & & & $D 7 B 7$ \\
\hline & & & $C P U$ & 32-bit \\
\hline & & & Type & executable \\
\hline & & & Indicat & $4 / 14$ \\
\hline & & & ors & \\
\hline 2 & Phackers & Exeinfo & $U P X 0$ & $9-3 . x x->$ \\
\hline & Check & & $\begin{array}{l}\text { Markus } \\
\text { ver. } 3\end{array}$ & \& Laszlo \\
\hline & & & unpack & upx.exe - d" \\
\hline & & & from & \\
\hline & & & http://ul & x.sf.net or \\
\hline & & & any $U P$ & /Generic \\
\hline & & & unpacke & \\
\hline & & &.$t e x t$ & \\
\hline & & & rdata & \\
\hline & & & data & \\
\hline 3 & Fuzzy & Md5sum & Sama & \\
\hline & Hashing & ssdeep & $100 \%$ & \\
\hline 4 & Analisa & Pestudio & $101 / 272$ & \\
\hline & Strings & & $w w w .15$ & 35ss.com \\
\hline & & Yara dan & OpenSc & Manager \\
\hline & & Strings & & \\
\hline & & & WININI & T.dll \\
\hline & & & http:// & \\
\hline & & & HTTP & \\
\hline & & & ExitPro & ess \\
\hline & & & CreateI & rocess \\
\hline & & & Internet & PpenUrl \\
\hline & & & Sleep & \\
\hline & & & GetSyst & mDirectory \\
\hline 5 & Malware & www.virus & Belum & \\
\hline & Scan & total.com & $\begin{array}{l}\text { terident } \\
\text { sebagai }\end{array}$ & $\begin{array}{l}\text { ikasi } \\
\text { nalware }\end{array}$ \\
\hline
\end{tabular}

Tabel 3. Hasil Analisa metode Runtime

\begin{tabular}{|c|c|c|c|c|c|}
\hline & & Analy & & & \\
\hline No & Temuan & & Runtime & alysis & \\
\hline & & Proc & Capture & Nori & Wir \\
\hline & & ess & BAT & ben & esh \\
\hline & & $\mathrm{Hac}$ & & Sanb & ark \\
\hline & & ker & & ox & \\
\hline 1 & $\begin{array}{l}\text { Penambahan } \\
\text { registry }\end{array}$ & - & $\checkmark$ & $\checkmark$ & - \\
\hline 2 & Penambahan & - & $\checkmark$ & $\checkmark$ & - \\
\hline & file baru pada & & & & \\
\hline & C:|Windows $\mid$ & & & & \\
\hline & system32 & & & & \\
\hline 3 & File hidden & - & $\checkmark$ & $\checkmark$ & - \\
\hline 4 & Alamat & - & - & - & $\checkmark$ \\
\hline & IP/web & & & & \\
\hline & Program : & & & & \\
\hline & www.1535ss. & & & & \\
\hline & com & & & & \\
\hline 5 & Nomor Port & - & - & - & $\checkmark$ \\
\hline & yang & & & & \\
\hline & digunakan: & & & & \\
\hline & 8080 & & & & \\
\hline 6 & Protocol yang & - & - & - & $\checkmark$ \\
\hline & digunakan; & & & & \\
\hline & NBNS & & & & \\
\hline 7 & File yang & $\checkmark$ & - & - & - \\
\hline & berjalan & & & & \\
\hline & dilatar & & & & \\
\hline & belakang & & & & \\
\hline
\end{tabular}

\section{KESIMPULAN}

Pada analisis yang terlah dilakukan dengan menggunakan kedua metode analisi malware yaitu Surfcae dan Runtime dapat dinyatakan bahwa : File "games.exe" jelas dapat dikatakan sebuah malware dikarenakan miliki strings yang pada umumnya terdapat sebuah malware. File dapat menggandakan diri ke folder system32 "WinHvaq32.exe" yang dibuktikan dengan kesamaan MD5. 


\section{UCAPAN TERIMA KASIH}

Saya ingin menyampaikan ucapan terimakasih yang sangat besar kepada Universitas Bina Darma dan Direktorat Riset dan Pengabdian Masyarakat Bina Darma (DRPM) atas dukungannya selama pengembangan karya penelitian ini.

\section{DAFTAR PUSTAKA}

[1] R. E. Indrajit, "Skenario Kombinasi Tools yang Efektif dalam Analisis Malware," Am. J. Appl. Sci., vol. 9, no. 3, pp. 1-22, 2011.

[2] T. A. Cahyanto, V. Wahanggara, and D. Ramadana, "Analisis dan Deteksi Malware Menggunakan Metode Malware Analisis Dinamis dan Malware Analisis Statis," Justindo, J. Sist. Teknol. Inf. Indones., vol. 2, no. 1, pp. 19-30, 2017.

[3] C. Indonesia, "Dua Rumah Sakit di Jakarta Kena Serangan Ransomware WannaCry," https://www.cnnindonesia.com. [Online]. Available: https://www.cnnindonesia.com/teknologi/201 70513191519-192-214642/dua-rumah-sakitdi-jakarta-kena-serangan-ransomwarewannacry. [Accessed: 05-Mar-2018].

[4] "Quick Count Malware Top Indonesia," Detikinet.com, 2014. [Online]. Available: https://inet.detik.com/security/d-

2640265/quick-count-malware-top-indonesia. [Accessed: 20-Mar-2018].

[5] Virustotal.com, "Virustotal," 2018. [Online]. Available:

https://www.virustotal.com/gui/home/upload. [Accessed: 05-May-2018].

[6] E. Haryanto, "Analisis Forensik WSO Webshell......Platform Linux.” .

[7] Y. A. Utomo et al., "Membangun Sistem Analisis Malware Pada Aplikasi Android Dengan Metode Reverse Engineering Menggunakan Remnux," vol. 4, no. 3, pp. 2000-2012, 2018.

[8] R. Yuvandra and M. Zulfin, "Analisis Kinerja Trafik Video Chatting Pada Sistem ClientClient Dengan Aplikasi Wireshark."

[9] Http://upx.sf.net, “upx,” 2018. [Online]. Available: http://upx.sf.net. [Accessed: 10May-2018]. 